Counseling supervisors: Standards for preparation and practice

By: H. Allan Dye and L. DiAnne Borders

This is the peer reviewed version of the following article:

Dye, H. A., \& Borders, L. D. (1990). Counseling supervisors: Standards for preparation and practice. Journal of Counseling \& Development, 69, 27-32.

which has been published in final form at https://doi.org/10.1002/j.15566676.1990.tb01449.x. This article may be used for non-commercial purposes in accordance with Wiley Terms and Conditions for Use of Self-Archived Versions.

***;(C) 1990 American Counseling Association. Reprinted with permission. No further reproduction is authorized without written permission from Wiley. This version of the document is not the version of record. Figures and/or pictures may be missing from this format of the document. $* * *$

\begin{abstract}
:
The emergence of counseling supervision as a professional specialty is reviewed, the need for standards of training and practice is explained, and the process by which the "Standards for Counseling Supervisors" came into existence is described. Current and potential options for their implementation are discussed.
\end{abstract}

Keywords: counseling supervision | standards | training

\title{
Article:
}

Over the last 10 years counseling supervision has emerged as a separate specialty within the counseling profession. Movement toward professional status has been spurred by several developments.

First, it has become increasingly apparent that effective counselors are not necessarily effective supervisors (cf. Bartlett, 1983; Holloway \& Hosford, 1983; Leddick \& Bernard, 1980).

Distinctions between counseling and supervision have been clarified in conceptual models of counselor and supervisor development (e.g., Hess, 1986, 1987; Loganbill, Hardy, \& Delworth, 1982; Stoltenberg, 1981; Stoltenberg \& Delworth, 1987) and in empirical descriptions of the supervision process (see reviews by Russell, Crimmings, \& Lent, 1984; Worthington, 1987). These writings suggest that supervisors have specific roles and goals. In essence, competent supervisors are not only competent counselors but are also able to convey their counseling knowledge and skills (i.e., create learning environments) in ways that promote a supervisee's effectiveness and professional identity.

Other developments have indicated that specialized training in supervision is desirable, perhaps necessary. A number of doctoral programs have added academic courses in supervision (Borders, 
in press; Borders \& Leddick, 1988; Loganbill et al., 1982; Sprenkle, 1988), and continuing education workshops are being offered routinely during annual conventions of professional organizations. In addition, instruction in supervision is now required in doctoral programs accredited by the Council for Accreditation of Counseling and Related Educational Programs (CACREP, 1988).

Another indication of professional status is the interest in supervisor credentialing. A separate credential for counseling supervisors has been proposed (Borders, 1989b; Dye, 1987; Hess, 1980; Schmidt \& Barret, 1983; Upchurch, 1985), and several have been created. Currently, the American Association for Marriage and Family Therapy (AAMFf, 1987) and the National Academy of Certified Clinical Mental Health Counselors (NACCMHC, 1987) certify "approved supervisors" of applicants to their counselor credentialing programs. In addition, the South Carolina counselor licensure board requires a separate license for supervisors of counselor licensure applicants (South Carolina Board of Examiners, 1987).

Despite these developments, supervision has not yet achieved the same professional status as counseling nor has counseling supervision been established as a professional specialty. Professions are defined by the standards upon which competency is based. In the case of counseling supervision, existing standards tend to be either brief and general (e.g., CACREP preparation standards for doctoral students) or meticulously specific (e.g., AAMFT guidelines for "approved supervisors"). If counseling supervision is to be recognized as a professional specialty, a comprehensive statement is needed to identify standards for supervisor preparation and practice that are applicable to the wide range of counselors that supervisors serve.

\section{DEVELOPMENT OF THE STANDARDS}

As early as 1982, the Supervision Interest Network of the Association for Counselor Education and Supervision (ACES) had begun a series of projects to identify core competencies of supervisors (Borders, 1989b). First, an inclusive list of competencies was created through a comprehensive review of the literature and a Delphi survey (see Borders \& Leddick, 1987, pp. 65-70). Second, ACES members were asked to rate the relative importance of these competencies (Dye, 1987; Dye \& Pride, 1987). Results of these two studies indicated that conceptual knowledge of the supervision process and various direct intervention skills were regarded as attributes of effective supervisors. Equally as important, however, were facilitative skills and personal traits (e.g., committed, encouraging, open, sensitive to the supervisee's needs and to individual differences). In general, relationship factors were considered to be as significant as technical skills in determining supervisory effectiveness.

These and other network projects (see Borders, 1989b) spurred interest in creating a generic credential for counseling supervisors. At the invitation of ACES President Joseph C. Rotter, representatives of various AACD divisions and counselor credentialing organizations met in September 1987 to discuss the feasibility of the credential. This group formed the ad hoc Interdivisional Task Force for Supervisor Credentialing (Task force, 1987). Based on the group's recommendations, the AACD Governing Council created the AA CD Supervisor Credentialing Task Force in March 1988 (Borders, 1988). The latter group was charged with investigating procedures for establishing a supervisor credential. 
During the summer of 1988, the task force was engaged in exploring with the National Board for Certified Counselors (NBCC) the feasibility of establishing a national supervisor certification program. No such determination has yet been made, but it became clear that for this to occur, it would first be necessary to develop standards upon which a supervisor credential could be based. Thus, an initial draft was written on behalf of the ACES Supervision Interest Network by H. Allan Dye and L. DiAnne Borders using competencies identified in the two ACES studies; a few additional competencies were added so that the standards represented a comprehensive definition of the counseling supervisor role. This draft was circulated for review to the ad hoc AACD Interdivisional Task Force on Supervision Credentialing (representatives from all AACD divisions and affiliates), to representatives of NBCC, to representatives of the American Association for State Counseling Boards (AASCB), and to members of the ACES Supervision Interest Network. Included in the total group were supervision practitioners from school, agency, and university settings along with researchers and supervisor educators. This review produced a number of changes that were incorporated into the current document. Thus, the Standards for Counseling Supervisors are the product of extraordinary interdivisional cooperation. They were endorsed by the ACES Executive Council in October 1988 (Dye, 1989), the AACD Governing Council in July 1989, and by AASCB in February 1990.

\section{CONTENT OF THE STANDARDS}

The "Standards" consist of 11 core areas of knowledge, competencies, and personal traits that characterize effective supervisors. They also include recommendations for sequential training experiences and professional activities. Extensive supervised counseling experience and a broad perspective of the field are considered prerequisites to supervision training. Graduate-level training in counseling supervision is to include didactic and experiential instruction, followed by continuing education experiences. In addition, supervisor practitioners conduct research to evaluate their effectiveness.

The Standards were written to encompass a wide spectrum of supervision practices and were designed to promote standards for supervisors of all counselors affiliated with the American Association for Counseling and Development (AACD). They also were intended to reflect the role of supervision in counselor development across the professional lifespan (i.e., preservice and postdegree counselors). As a result, core areas of the Standards describe supervision skills, traits, and knowledge that are "generic" to the supervision process.

\section{IMPLEMENTATION OF THE STANDARDS}

The Standards are recommendations for the knowledge, competencies, traits, and experience that counseling supervisors should demonstrate. Tangible impact on the counseling and supervision professions, however, is dependent on the actions of various professional organizations and regulatory bodies. Following are suggestions for implementing the Standards; actions already taken toward these goals are summarized within each suggestion.

First, the Standards should be publicized by AACD. Promulgation of the Standards would demonstrate AACD's continued leadership role in setting professional standards that help ensure 
quality training for counselors and quality service for clients. This seems especially appropriate in light of the interdivisional cooperation that has made possible the Standards' rapid creation and adoption.

Second, the Standards can be used to design training programs for supervisors. The Standards delineate content areas and skills that need to be included in academic courses and in continuing education workshops or inservice training programs for practicing supervisors (i.e., field supervisors and counselor educators). In particular, the Standards provide a basis for revising and improving CACREP preparation standards for supervision instruction in doctoral programs.

Third, the Standards should be incorporated into existing counselor credentials. Multiple levels of "enforcement" are possible, from educational services to mandated compliance. Several of these possibilities already are in effect. Recently, for example, the NBCC newsletter included suggestions for choosing a supervisor that were based on the Standards (Borders, 1989a). To further inform its members, NBCC also offered to send them complete copies of the Standards.

In addition, several state counselor licensure boards have used (or are using) the Standards to write regulations for "approved supervisors" of counselor applicants, and other boards have expressed interest (board members at AASCB meeting, personal correspondence, February 3, 1990). Within AASCB, a standing Committee on Supervision is addressing relevant regulatory, practical, ethical, and legal issues in writing supervisor regulations. Finally, Bloom et al. (1990) also cited the Standards as criteria for "approved supervisors" in their model licensure bill.

Similar actions could be included in the certification process for school counselors. In fact, a separate certification category of counseling supervisors for practicing school counselors might be created (AACD School Counseling Task Force, 1989; Schmidt \& Barret, 1983).

Another possibility is the creation of a separate generic credential for supervisors. Although such a credential has generated some interest (Borders, 1989b; Dye, 1987), there are indications of concern about the increasing number of professional certifications. In addition, a supervisor credential may not be the most feasible or powerful approach to implementing the Standards. For example, it may be more judicious to encourage state counseling licensure boards to incorporate the Standards. In this case, ACES and AACD members might serve as advisers and consultants to state board members.

\section{CONCLUSION}

The Standards for Counseling Supervisors have contributed to the increasing visibility and status of this professional specialty. The ultimate level of professional maturity, however, will be measured by the manner in which the Standards are implemented. As we move forward, the fundamental goal-effective supervisors for competent counselors to ensure quality service for clients-should not be forgotten.

\section{REFERENCES}


AACD School Counseling Task Force. (1989). School counseling: A profession at risk [Final Report]. Alexandria, VA: Author.

American Association for Marriage and Family Therapy (AAMFT) (1987). The approved supervisor designation. Washington, DC: Author.

Bartlett, W. E. (1983). A multidimensional framework for the analysis of supervision of counseling. The Counseling Psychologist, 11(1), 9-17.

Bloom, J., Gerstein, L., Tarvydas, V., Conaster, J., Davis, E., Kater, D., Sherrard, P., \& Esposito, R. (1990). Model legislation for licensed professional counselors. Journal of Counseling and Development, 68, 511-523.

Borders, L. D. (1988, Summer). Supervisor credentialing. ACES Spectrum, 48(4), 11.

Borders, L. D. (in press). Training programs for supervisors. In A. K. Hess (Ed.), Psychotherapy supervision: Theory, research and practice (Vol. II). New York: Wiley.

Borders, L. D. (1989a). Choosing a counseling supervisor. NBCC News Notes, 6(1), 5.

Borders, L. D. (1989b). Credentialing supervisors: A commitment to professionalism. Illinois Association for Counseling and Development Quarterly, 112, 33-42.

Borders, L. D., \& Leddick, G. R. (1987). Handbook of Counseling Supervision. Alexandria, VA: American Association for Counseling and Development.

Borders, L. D., \& Leddick, G. R. (1988). A nationwide survey of supervision training. Counselor Education and Supervision, 27, 271-283.

Council for Accreditation of Counseling and Related Educational Programs. (1988, July). Accreditation procedures manual and application. Alexandria, VA: Author.

Dye, H. A. (1987). Supervision-ACES' attitudes: Supervisor competencies and a national certification program. ACES Spectrum, 47(4), 2-3.

Dye, H. A. (1989). ACES adopts Standards for Counseling Supervisors. ACES Spectrum, 49(3), 7-10.

Dye, H. A., \& Pride, K. (1987, April). ACES' attitudes: Supervisor competencies and a national certification program. Presentation at the annual meeting of the American Association for Counseling and Development, New Orleans, LA.

Hess, A. K. (Ed.). (1980). Psychotherapy supervision: Theory, research and practice. New York: Wiley. 
Hess, A. K. (1986). Growth in supervision: Stages of supervisee and supervisor development. The Clinical Supervisor, 4(1-2), 51-67.

Hess, A. K. (1987). Psychotherapy supervision: Stages, Buber, and a theory of relationship. Professional Psychology, 18, 251-259.

Holloway, E. L., \& Hosford, R. E. (1983). Towards developing a prescriptive technology of counselor supervision. The Counseling Psychologist, 11(1), 73-77.

Leddick, G. R., \& Bernard, J. M. (1980). The history of supervision: A critical review. Counselor Education and Supervision, 19, 186-196.

Loganbill, C., Hardy, E., \& Delworth, U. (1982). Supervision: A conceptual model. The Counseling Psychologist, 10(1), 3-42.

NACCMHC approves standards. (1987, September 10). Guidepost, p. 14.

Russell, R. K., Crimmings, A. M., \& Lent, R. W. (1984). Counselor training and supervision: Theory and research. In S. D. Brown \& R. W. Lent (Eds.), Handbook of counseling psychology (pp. 625-681). New York: Wiley.

Schmidt, J. J., \& Barret, R. L. (1983). Who's in charge? School counseling supervision in North Carolina. Counselor Education and Supervision, 23, 109-116.

South Carolina Board of Examiners for Licensed Professional Counselors, Associate Counselors, and Marital and Family Therapists. (1987, November). Policy statement: Supervision of licensed professional counselors and licensed associate counselors and licensure of counselor supervisors and registration of counselor supervisors-in-training. Columbia, SC: Author.

Sprenkle, D. H. (1988). Training and supervision in degree-granting graduate programs in family therapy. In H. A. Liddle, D. C. Breunlin, \& R. C. Schwartz (Eds.), Handbook of family therapy training and supervision (pp. 233-248). New York: Guilford.

Stoltenberg, C. (1981). Approaching supervision from a developmental perspective: The counselor complexity model. Journal of Counseling Psychology, 28, 59-65.

Stoltenberg, C. D., \& Delworth, U. (1987). Supervising counselors and therapists: A developmental approach. San Francisco: Jossey-Bass.

Task force to create supervision criteria. (1987, November 26). Guidepost, pp.4-5.

Upchurch, D. W. (1985). Ethical standards and the supervisory process. Counselor Education and Supervision, 25, 90-98.

Worthington, E. L., Jr. (1987). Changes in supervision as counselors and supervisors gain experience: A review. Professional Psychology, 18, 189-208. 